OPEN ACCESS

Edited by:

Jun Chen,

University of Science and Technology

Beijing, China

Reviewed by:

Xuehua Yan,

Jiangsu University, China

Ying Sun,

Beihang University, China

*Correspondence:

Erjun Liang

ejliang@zzu.edu.cn

Specialty section: This article was submitted to Physical Chemistry and Chemical

Physics,

a section of the journal

Frontiers in Chemistry

Received: 15 January 2018 Accepted: 29 March 2018

Published: 17 April 2018

Citation:

Li S, Ge X, Yuan H, Chen D, Guo J, Shen R, Chao M and Liang E (2018) Near-Zero Thermal Expansion and Phase Transitions in $\mathrm{HFMg}_{1-x} \mathrm{Zn}_{x} \mathrm{Mo}_{3} \mathrm{O}_{12}$.

Front. Chem. 6:115.

doi: 10.3389/fchem.2018.00115

\section{Near-Zero Thermal Expansion and Phase Transitions in $\mathrm{HfMg}_{1-x} \mathrm{Zn}_{x} \mathrm{Mo}_{3} \mathrm{O}_{12}$}

\author{
Sailei Li ${ }^{1}$, Xianghong Ge 1,2, Huanli Yuan 1,3, Dongxia Chen ${ }^{1}$, Juan Guo ${ }^{1}$, Ruofan Shen ${ }^{1}$, \\ Mingju Chao ${ }^{1}$ and Erjun Liang ${ }^{1 *}$
}

${ }^{1}$ School of Physical Science \& Engineering and Key Laboratory of Materials Physics of Ministry of Education, Zhengzhou University, Zhengzhou, China, ${ }^{2}$ College of Science, Zhongyuan University of Technology, Zhengzhou, China, ${ }^{3}$ Department of Physics and Electronic Engineering, Zhoukou Normal University, Zhoukou, China

The effects of $\mathrm{Zn}^{2+}$ incorporation on the phase formation, thermal expansion, phase transition, and vibrational properties of $\mathrm{HfMg}_{1-x} \mathrm{Zn}_{x} \mathrm{Mo}_{3} \mathrm{O}_{12}$ are investigated by $\mathrm{XRD}$, dilatometry, and Raman spectroscopy. The results show that (i) single phase formation is only possible for $x \leq 0.5$, otherwise, additional phases of $\mathrm{HfMo}_{2} \mathrm{O}_{8}$ and $\mathrm{ZnMoO}_{4}$ appear; (ii) The phase transition temperature from monoclinic to orthorhombic structure of the single phase $\mathrm{HfMg}_{1-x} \mathrm{Zn}_{x} \mathrm{Mo}_{3} \mathrm{O}_{12}$ can be well-tailored, which increases with the content of $\mathrm{Zn}^{2+}$; (iii) The incorporation of $\mathrm{Zn}^{2+}$ leads to an pronounced reduction in the positive expansion of the $b$-axis and an enhanced negative thermal expansion (NTE) in the $c$-axes, leading to a near-zero thermal expansion (ZTE) property with lower anisotropy over a wide temperature range; (iv) Replacement of $\mathrm{Mg}^{2+}$ by $\mathrm{Zn}^{2+}$ weakens the $\mathrm{Mo}-\mathrm{O}$ bonds as revealed by obvious red shifts of all the Mo-O stretching modes with increasing the content of $\mathrm{Zn}^{2+}$ and improves the sintering performance of the samples which is observed by SEM. The mechanisms of the negative and near-ZTE are discussed.

Keywords: thermal expansion, near-zero thermal expansion, phase transition, X-ray diffraction (XRD), Raman spectrum

\section{INTRODUCTION}

Large difference in coefficients of thermal expansion (CTE) of materials could lead to performance deterioration and even failure of devices due to thermal stress when temperature changes abruptly or frequently. Since most materials expand on heating and contract on cooling, materials with opposite property, namely negative thermal expansion (NTE), are particularly desired for tailoring CTEs. The rediscovery of NTE in $\mathrm{ZrW}_{2} \mathrm{O}_{8}$ in a wide temperature range (Evans et al., 1996, 1997a) triggered continuous efforts on understanding the NTE phenomenon and searching for more NTE materials (Yang et al., 2007; Chen et al., 2013, 2015; Tallentire et al., 2013; Lama et al., 2014; Liu et al., 2014; Peng et al., 2014; Xiao et al., 2014; Hu et al., 2015). To date, different families of NTE materials based on various mechanisms, such as the phonon effect (Pryde et al., 1996; Wang et al., 2011; Bridges et al., 2014; Cheng et al., 2016a; Ge et al., 2016a), magnetovolume effect (Takenaka and Takagi, 2005; Qu et al., 2012; Yan et al., 2014), spontaneous ferroelectric polarization (Chen et al., 2013; Peng et al., 2016), and charge transfer (Long et al., 2009; Azuma et al., 2011; Yamada et al., 2016) have been reported. Among the materials, the family of $\mathrm{A}_{2} \mathrm{M}_{3} \mathrm{O}_{12}$ ( $\mathrm{A}=$ transition metal or a mixture of tetravalent and bivalent cations, $\mathrm{M}=\mathrm{W}, \mathrm{Mo}$ ) have been particularly attractive, because whose NTEs go over a wide temperature range and can be tuned 
from low positive to large negative values due to chemical flexibility (Evans et al., 1997b; Suzuki and Omote, 2006; Wu et al., 2009, 2012, 2014; Li et al., 2011; Das et al., 2013; Miller et al., 2013; Song et al., 2014a; Liu et al., 2015; Chen et al., 2016; Cheng et al., 2016a).

In recent years, a number of novel NTE materials have been designed based on the basic structure of $\mathrm{A}_{2} \mathrm{M}_{3} \mathrm{O}_{12}$ family, including those with a general formula $\mathrm{ABM}_{3} \mathrm{O}_{12}$ where $\mathrm{A}$ is tetravalent $\mathrm{Hf}^{4+}$ or $\mathrm{Zr}^{4+}$ and $\mathrm{B}$ is bivalent cation $\mathrm{Mg}^{2+}$ or $\mathrm{Mn}^{2+}$, and $\mathrm{M}$ is $\mathrm{W}$ or Mo or a combination of them (Suzuki and Omote, 2004; Baiz et al., 2008; Gindhart et al., 2008; Marinkovic et al., 2008; Song et al., 2013; Li et al., 2014, 2016, 2017; Ge et al., 2016a; Liu et al., 2018) and those with a formula $\mathrm{ABM}_{2} \mathrm{XO}_{12}$ where $\mathrm{A}$ and $\mathrm{M}$ are the same as in $\mathrm{ABM}_{3} \mathrm{O}_{12}, \mathrm{~B}$ is a trivalent cation and $\mathrm{X}$ is $\mathrm{P}^{5+}$ or $\mathrm{V}^{5+}$ (Chen et al., 2016; Cheng et al., 2016b, 2017; Ge et al., 2016b,c). The most distinct characteristics of the materials with formula $\mathrm{ABM}_{2} \mathrm{XO}_{12}$ are that they exhibit NTE over a wide temperature range and intense photoluminescence in the visible range. Nearly an order higher ionic conductivity was observed for $\mathrm{HfMgW}_{3} \mathrm{O}_{12}$ with respect to the family $\mathrm{A}_{2} \mathrm{M}_{3} \mathrm{O}_{12}$ (Omote et al., 2011). $\mathrm{HfMgMo}_{3} \mathrm{O}_{12}$ with a linear CTE of 1.02 $\times 10^{-6} \mathrm{~K}^{-1}$ from 298 to $1013 \mathrm{~K}$ was reported by Marinkovic et al. (2008). It crystallizes in orthorhombic symmetry with space group Pnma(62) or $P_{n a 2}$ (33) and transforms to monoclinic structure at $175 \mathrm{~K}$ (Miller et al., 2012).

In this paper, we investigate the effects of $\mathrm{Zn}^{2+}$ incorporation on the structure, phase transition, thermal expansion, and vibrational properties of $\mathrm{HfMgMo}_{3} \mathrm{O}_{12}$. It is shown that single phase solid solution of $\mathrm{HfMg}_{1-x} \mathrm{Zn}_{x} \mathrm{Mo}_{3} \mathrm{O}_{12}$ can be achieved only for the compositions of $x \leq 0.5$, otherwise, additional phases of $\mathrm{HfMo}_{2} \mathrm{O}_{8}$ and $\mathrm{ZnMoO}_{4}$ appear. The monoclinic to orthorhombic phase transition temperature increases with the content of $\mathrm{Zn}^{2+}$ for $x \leq 0.5$ so that $\mathrm{HfMg}_{0.5} \mathrm{Zn}_{0.5} \mathrm{Mo}_{3} \mathrm{O}_{12}$ crystallizes in monoclinic phase and all other samples $(x \leq$ 0.4 ) adopt orthorhombic structure at room temperature (RT). The incorporation of $\mathrm{Zn}^{2+}$ alters the axial CTE differently for each axis and finally results in near-zero thermal expansion
(ZTE) property over wide temperature ranges with smaller thermal expansion anisotropy with respect to $\mathrm{HfMgMo}_{3} \mathrm{O}_{12}$. The mechanisms of $\mathrm{Zn}^{2+}$ incorporation on the phase transition, thermal expansion and vibrational properties are discussed.

\section{EXPERIMENTAL}

Analytic grade reagents of $\mathrm{HfO}_{2}, \mathrm{MgO}, \mathrm{ZnO}$, and $\mathrm{MoO}_{3}$ were mixed with stoichiometric ratios for $\mathrm{HfMg}_{1-x} \mathrm{Zn}_{x} \mathrm{Mo}_{3} \mathrm{O}_{12}$ with $x=0.0,0.1,0.2,0.3,0.4,0.5,0.6,0.7,0.8$, and 1.0 . The mixtures were ground in an agate mortar for $2 \mathrm{~h}$, then, pressed under 325 $\mathrm{MPa}$ into cylinders with diameter of $10 \mathrm{~mm}$ and height of $6 \mathrm{~mm}$ using a uniaxial tablet machine. The cylinders were sintered at $1,073 \mathrm{~K}$ for $5 \mathrm{~h}$ in a muffle furnace in air and cooled down to $300 \mathrm{~K}$ naturally.

The as-prepared samples were analyzed by XRD with a PANalytical X'Pert PRO X-ray Diffractometer to identify the crystalline phase. Variable-temperature X-ray powder data were collected on a Rigaku (Japan, SmartLab 3KW) diffractometer with $\mathrm{Cu} \mathrm{K} \alpha(\lambda=0.15405 \mathrm{~nm})$ radiation. Diffraction data were collected with a step size of $0.01^{\circ}$ in the $2 \theta$ range of $10^{\circ}-$ $120^{\circ}$. The sample was heated at a rate of $10 \mathrm{~K} / \mathrm{min}$ and remained at each measurement temperature for $5 \mathrm{~min}$ before measurement. Unit cell dimensions above the phase transition temperature were determined with software of PowderX. Variable-temperature/RT Raman spectra were recorded with A LabRAM HR Evolution Raman spectrometer (France HORIBA JobinYvon S.A.A.) equipped with a Linkam THMS600 Heating and Freezing Stage (Japan Hightech) (an accuracy of $\pm 0.1 \mathrm{~K}$ ). The excitation wavelength is $633 \mathrm{~nm}$ and low excitation laser power is necessary to avoid local heating by the laser. The microstructures and energy dispersive spectra of the samples were examined with a scanning electron microscope (SEM, Model Quanta 250). The relative length changes were measured with LINSEIS DIL L75 dilatometer at the heating and cooling rates of $5 \mathrm{~K} / \mathrm{min}$.
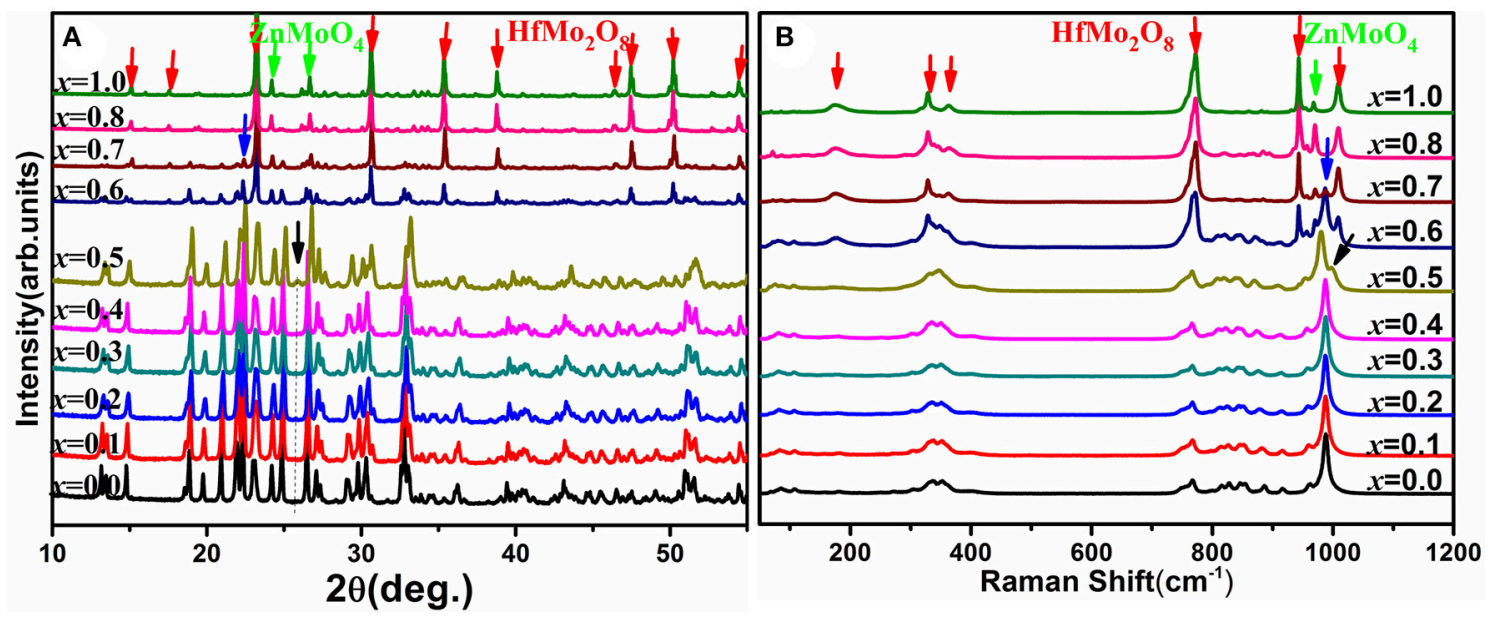

FIGURE 1 | (A) X-ray diffraction patterns of the solid solutions of $\mathrm{HfMg}_{1-x} \mathrm{Zn}_{x} \mathrm{Mo}_{3} \mathrm{O}_{12}$; (B) Raman spectra of the solid solutions of $\mathrm{HfMg}{ }_{1-x} \mathrm{Zn} \mathrm{Mo}_{3} \mathrm{O}_{12}$. 


\section{RESULTS AND DISCUSSION}

Figure 1A shows the XRD patterns of the solid solutions of $\mathrm{HfMg}_{1-x} \mathrm{Zn}_{x} \mathrm{Mo}_{3} \mathrm{O}_{12}$. When $x=0.0$, the diffraction peaks are corresponding to $\mathrm{HfMgMo}_{3} \mathrm{O}_{12}$, which adopts an orthorhombic structure with space group Pnma or Pna2 1 (Marinkovic et al., 2008). No obvious changes in the XRD patterns could be observed with increasing the content of $\mathrm{Zn}^{2+}$ till $x=0.4$. It is reasonable to conclude that $\mathrm{HfMg}_{1-x} \mathrm{Zn}_{x} \mathrm{Mo}_{3} \mathrm{O}_{12}$ for $x \leq 0.4$ crystallized in an orthorhombic structure. Nevertheless, some subtle changes are observed for $x=0.5$, such as the weak peak appearing at about $25.6^{\circ}$ which is characteristic for a monoclinic structure (Song et al., 2014b; Ge et al., 2016a) of $\mathrm{ABMo}_{3} \mathrm{O}_{12}$. $\mathrm{HfMg}_{0.5} \mathrm{Zn}_{0.5} \mathrm{Mo}_{3} \mathrm{O}_{12}$ at $\mathrm{RT}$ is thus identified as a monoclinic structure. The XRD patterns change obviously with further increasing content of $\mathrm{Zn}^{2+}$. Detailed analyses show that the newly appeared peaks correspond well to $\mathrm{HfMo}_{2} \mathrm{O}_{8}$ and $\mathrm{ZnMoO}_{4}$ (Reichelt et al., 2000; Allen et al., 2004), respectively.

The above analysis is supported by Raman spectroscopic analysis (Figure 1B). The Raman spectra are consistent with each other for $x \leq 0.4$ while the Raman band at $988 \mathrm{~cm}^{-1}$ splits into two bands at 980 and $998 \mathrm{~cm}^{-1}$ for $x=0.5$ (as indicated by the black arrowhead), which is characteristic for a phase transition from higher orthorhombic symmetry to lower monoclinic symmetry (Li et al., 2011; Ge et al., 2016a) for the $\mathrm{ABMo}_{3} \mathrm{O}_{12}$ family. Distinct changes of the Raman spectra occur for higher content of $\mathrm{Zn}^{2+}$. The new Raman bands at about $175,328,362,772,943$, and $1,008 \mathrm{~cm}^{-1}$ correspond well to $\mathrm{HfMo}_{2} \mathrm{O}_{8}$ (Liang et al., 2008b) and that around $968 \mathrm{~cm}^{-1}$ arises from $\mathrm{ZnMoO}_{4}$ (Ahsaine et al., 2016). Both XRD and Raman analyses demonstrate that a single phase solid solution of $\mathrm{HfMg}_{1-x} \mathrm{Zn}_{x} \mathrm{Mo}_{3} \mathrm{O}_{12}$ is only possible for $x \leq 0.5$ and additional phases of $\mathrm{HfMo}_{2} \mathrm{O}_{8}$ and $\mathrm{ZnMoO}_{4}$ form for $x \geq 0.6$. At RT, $\mathrm{HfMg}_{1-x} \mathrm{Zn}_{x} \mathrm{Mo}_{3} \mathrm{O}_{12}$ for $x \leq 0.4$ adopt an orthorhombic structure while $\mathrm{HfMg}_{0.5} \mathrm{Zn}_{0.5} \mathrm{Mo}_{3} \mathrm{O}_{12}$ crystallizes in a monoclinic structure.

Raman spectroscopy is very sensitive to the monoclinic-toorthorhombic phase transition (Li et al., 2011, 2016; Ge et al., 2016a). In order to get some insights into the influence of $\mathrm{Zn}^{2+}$ on the phase transition, we carried out temperature-dependent

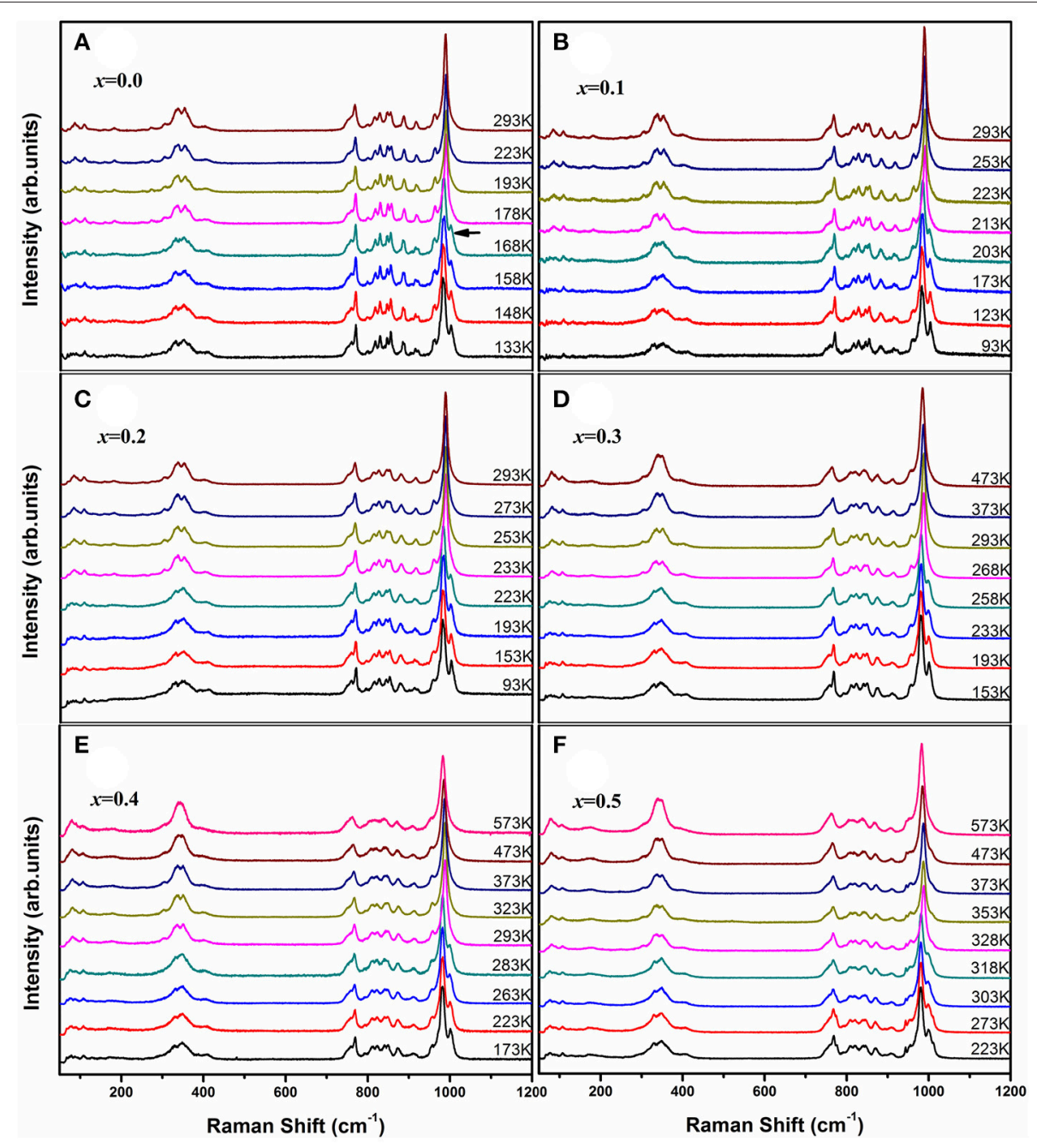

FIGURE 2 | Temperature-dependent Raman spectra of $\mathrm{HfMg}_{1-x} \mathrm{Zn}_{x} \mathrm{Mo}_{3} \mathrm{O}_{12}$ with $x=0.0$ (A), 0.1 (B), 0.2 (C), 0.3 (D), 0.4 (E), and 0.5 (F). 
Raman spectral observation of $\mathrm{HfMg}_{1-x} \mathrm{Zn}_{x} \mathrm{Mo}_{3} \mathrm{O}_{12} \quad(x \leq$ $0.5)$ as shown in Figure 2. The XRD analyses suggest that $\mathrm{HfMg}_{1-x} \mathrm{Zn}_{x} \mathrm{Mo}_{3} \mathrm{O}_{12}(x \leq 0.5)$ have similar open framework structure as $\mathrm{HfMgMo}_{3} \mathrm{O}_{12}$. In the orthorhombic phase, there are four molecular formulas in a unit cell, in which each $\mathrm{MoO}_{4}$ tetrahedron sharing its four vortexes with $\mathrm{HfO}_{6} / \mathrm{MgO}_{6}$ octahedra and each $\mathrm{HfO}_{6} / \mathrm{MgO}_{6}$ octahedron shares its corners with six $\mathrm{MoO}_{4}$ tetrahedra. Hf and $\mathrm{Mg}$ are alternatively aligned in the [010] direction forming a quasi-layered structure (Omote et al., 2011). The Raman modes from 1,050 to $900 \mathrm{~cm}^{-1}$, from 900 to $750 \mathrm{~cm}^{-1}$, from 400 to $320 \mathrm{~cm}^{-1}$, and from 320 to $280 \mathrm{~cm}^{-1}$ are identified as symmetric stretching $\left(\nu_{1}\right)$, asymmetric stretching $\left(v_{3}\right)$, asymmetric bending $\left(v_{4}\right)$, and symmetric bending $\left(v_{2}\right)$ modes in the $\mathrm{MoO}_{4}$ tetrahedra, respectively (Liang et al., 2008a; Li et al., 2011). Figure $\mathbf{2 A}$ shows the temperature dependent Raman spectra of $\mathrm{HfMgMo}_{3} \mathrm{O}_{12}$. The most distinctive change of the Raman spectra is the disappearance of the band at about $1,001 \mathrm{~cm}^{-1}$ with temperature increase from 168 to $178 \mathrm{~K}$, which can be regarded as characteristic of the phase transition from low temperature monoclinic to high temperature orthorhombic structure (Li et al., 2011; Ge et al., 2016a). The phase transition temperature agrees well with the result derived from XRD analysis (Miller et al., 2012). In Figures 2B-F we present the temperature dependent Raman spectra for $\mathrm{Zn}^{2+}$-containing samples. It is shown that the vanishing of the characteristic Raman band for the monoclinic structure occurs in the ranges of $168-178,203-213,223-233,258-268,283-293$, and $318-328 \mathrm{~K}$ for $x=0.0,0.1,0.2,0.3,0.4$, and 0.5 , respectively, demonstrating that the phase transition temperature increases with the content of $\mathrm{Zn}^{2+}$.

In the orthorhombic structure of $\mathrm{HfMg}_{1-x} \mathrm{Zn}_{x} \mathrm{Mo}_{3} \mathrm{O}_{12}(x \leq$ 0.5), the four vortexes of each $\mathrm{MoO}_{4}$ tetrahedron are shared with two $\mathrm{HfO}_{6}$ and two $\mathrm{MgO}_{6} / \mathrm{ZnO}_{6}$ octahedra while each $\mathrm{HfO}_{6} / \mathrm{MgO}_{6} / \mathrm{ZnO}_{6}$ octahedron shares its corners with six $\mathrm{MoO}_{4}$ tetrahedra. Statistically, each $\mathrm{MoO}_{4}$ tetrahedron links to $0.0,0.2$, $0.4,0.8$, and $1.0 \mathrm{ZnO}_{6}$ octahedron for $x=0.0,0.1,0.2,0.3$, 0.4 , and 0.5 . Since the ionic radius of $\mathrm{Zn}^{2+}$ is $74 \mathrm{pm}$ which is slightly larger than that of $\mathrm{Mg}^{2+}(72 \mathrm{pm})$, large lattice distortion and increase in phase transition temperature is not expected if only the ionic radius is considered. The experimentally observed obvious increase in phase transition temperature is therefore attributed to the difference in electronegativity between $\mathrm{Zn}^{2+}$ (1.65 Pauling) and $\mathrm{Mg}^{2+}$ (1.31 Pauling). Replacement of $\mathrm{Mg}^{2+}$ by $\mathrm{Zn}^{2+}$ causes an increase in electronegativity at the $\mathrm{Zn}^{2+}$. cation side and a decrease in the effective negative charge on oxygen, and hence a decrease in the oxygen-oxygen repulsion. With increasing the content of $\mathrm{Zn}^{2+}$, oxygen-oxygen attractive forces increase, causing the network collapse transition to occur at higher temperatures (Evans et al., 1997b).

Figure 3 shows the relative length changes of sintered cylinders with increasing temperature measured by dilatometry. All the samples for $x \leq 0.6$ exhibit abrupt length increase around the temperature of monoclinic to orthorhombic phase transition. The phase transition temperature increases with increasing the content of $\mathrm{Zn}^{2+}$ except the one for $x=0.6$ whose phase transition temperature is lower than that of $x \leq 0.5$ due to the generation of $\mathrm{HfMo}_{2} \mathrm{O}_{8}$ and $\mathrm{ZnMoO}_{4}$. In this case, it can be deduced that the real content of $\mathrm{Zn}^{2+}$ in $\mathrm{HfMg}_{1-x} \mathrm{Zn}_{x} \mathrm{Mo}_{3} \mathrm{O}_{12}$ is lower than $\mathrm{HfMg}_{0.5} \mathrm{Zn}_{0.5} \mathrm{Mo}_{3} \mathrm{O}_{12}$. These results comply well with the above Raman spectroscopic analyses. The CTEs are calculated from the relative length change and shown in the Table 1. It indicates that all the single phase samples present excellent near-ZTE property above the phase transition temperature. It is interesting to notice that even for the multi-phase samples for $x=0.8$ and 1.0, a near-ZTE property in a wide temperature range are realized. However, in this paper we focus on the effect of $\mathrm{Zn}^{2+}$ incorporation on the structure and properties of the single phase $\mathrm{HfMg}_{1-x} \mathrm{Zn}_{x} \mathrm{Mo}_{3} \mathrm{O}_{12}$.

In order to get insight into the axial thermal expansion property, we carried out temperature-dependent powder XRD measurements for the samples of $x=0.2$ and 0.3 . For comparison, variable-temperature XRD data of $\mathrm{HfMgMo}_{3} \mathrm{O}_{12}$ were also collected. Figure $4 \mathrm{~A}$ shows the selected temperaturedependent XRD patterns for $\mathrm{HfMg}_{0.7} \mathrm{Zn}_{0.3} \mathrm{Mo}_{3} \mathrm{O}_{12}$ at different temperatures. It is obvious that its $\mathrm{XRD}$ pattern changes distinctively around $225 \mathrm{~K}$, which is attributed to the phase transformation from lower temperature monoclinic to higher temperature orthorhombic structure. Lattice constants and cell volume at each temperature are calculated and given in Figure 4B. It is evident that the $a$ - and $c$ axes contract while the $b$-axis expands with increasing temperature. The CTEs for the $a-, b-$, and $c$-axes and

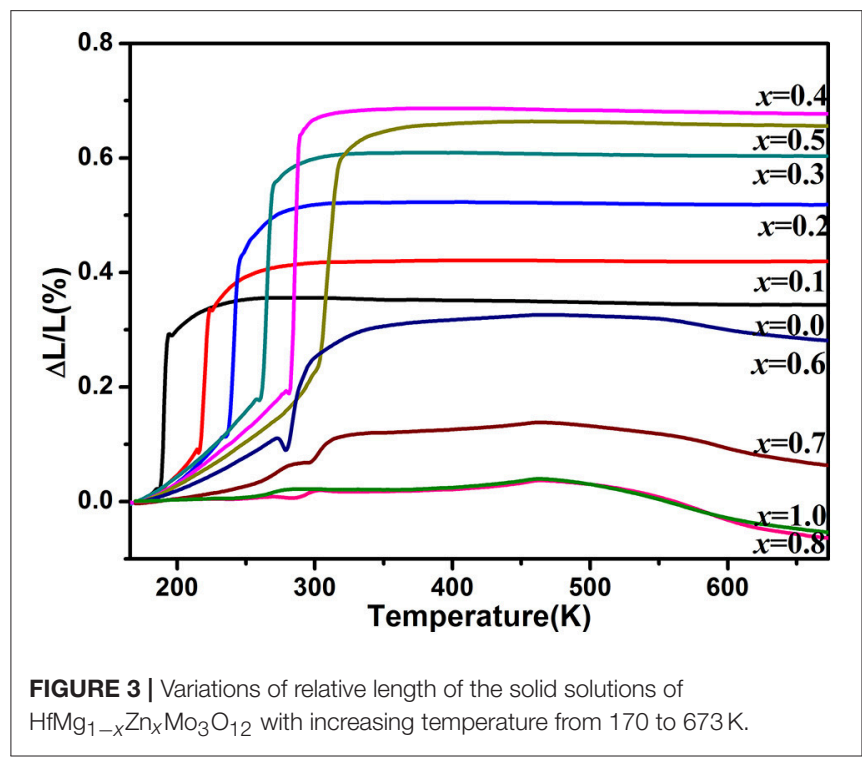

TABLE 1 | Values of CTES of $\mathrm{HFMg}_{1-x} \mathrm{Zn}_{x} \mathrm{Mo}_{3} \mathrm{O}_{12}$.

\begin{tabular}{lcc}
\hline Samples $(\boldsymbol{x})$ & CTEs $\left(\mathbf{1 0}^{-\mathbf{6}} \mathbf{K}^{-\mathbf{1}}\right)$ & Fit range (K) \\
\hline 0.0 & -0.21 & $248-673$ \\
0.1 & 0.05 & $303-673$ \\
0.2 & -0.05 & $308-673$ \\
0.3 & -0.09 & $323-673$ \\
0.4 & -0.11 & $343-673$ \\
0.5 & -0.11 & $373-673$
\end{tabular}



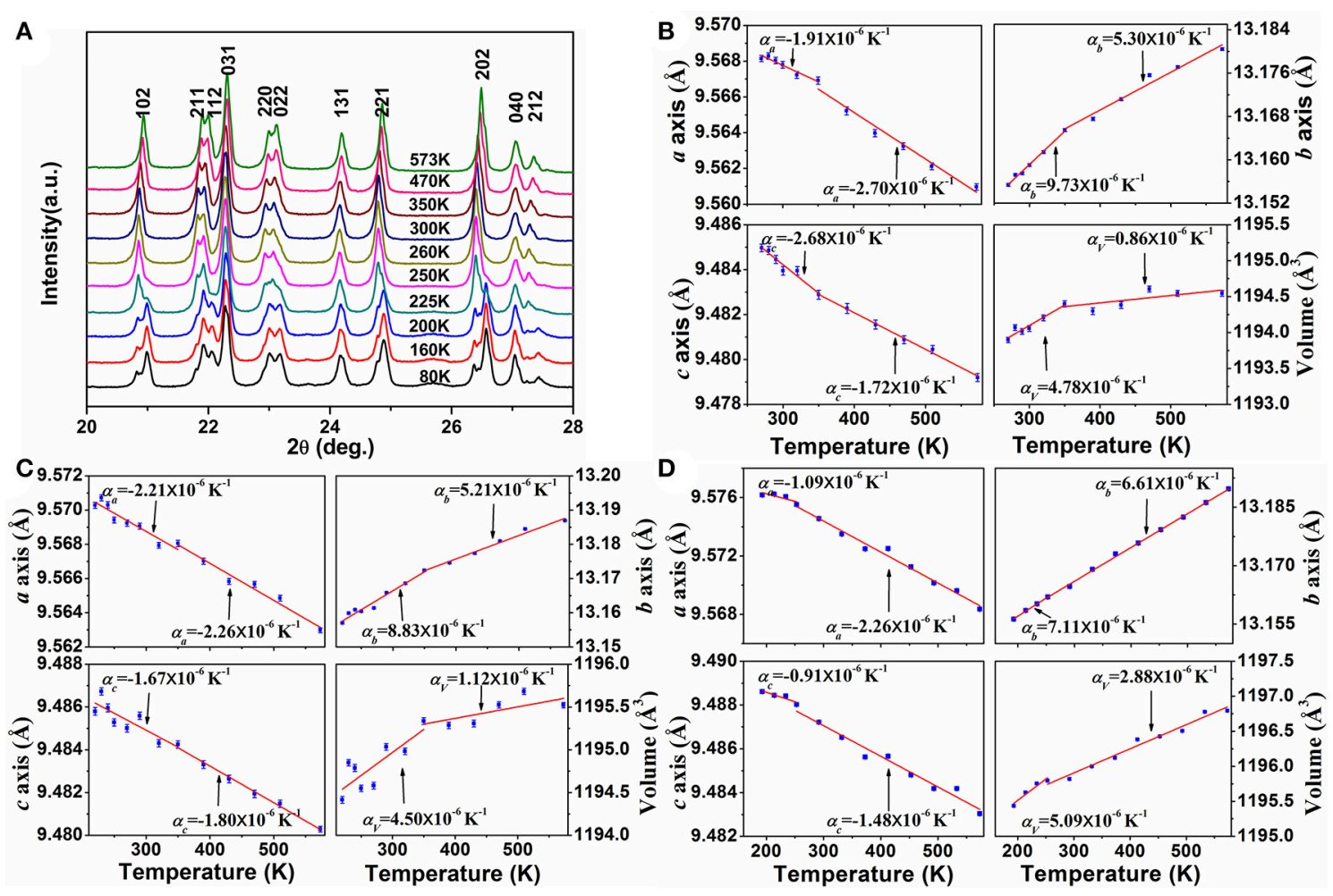

FIGURE 4 | (A) Variable-temperature XRD patterns of $\mathrm{HfMg}_{0.7} \mathrm{Zn}_{0.3} \mathrm{Mo}_{3} \mathrm{O}_{12}$ (The XRD patterns were measured for $2 \theta=10^{\circ}-120^{\circ}$, here only a small range is shown for clarity); Changes of lattice constants and volume of $\mathrm{HfMg}_{1-x} \mathrm{Zn}_{x} \mathrm{Mo}_{3} \mathrm{O}_{12}$ with temperature: (B) for $x=0.3$, (C) for $x=0.2$, (D) for $\mathrm{HfMgMo}_{3} \mathrm{O}_{12}$.

volume are calculated to be $\alpha_{a}=-2.70 \times 10^{-6} \mathrm{~K}^{-1}$, $\alpha_{b}=5.30 \times 10^{-6} K^{-1}, \alpha_{c}=-1.72 \times 10^{-6} K^{-1}$, $\alpha_{V}=0.86 \times 10^{-6} K^{-1}(350-573 K)$, respectively. This gives rise to a linear CTE $\alpha_{l}=0.29 \times 10^{-6} \mathrm{~K}^{-1}$. Similar axial thermal expansion behaviors are obtained for $\mathrm{HfMg}_{0.8} \mathrm{Zn}_{0.2} \mathrm{Mo}_{3} \mathrm{O}_{12}$ from temperature dependent XRD measurements (not shown here). The changes of its lattice constants and volume with temperature are given in Figure 4C. The CTEs for the $a$-, $b$-, and $c$-axes and volume are calculated to be $\alpha_{a}=-2.26 \times 10^{-6} \mathrm{~K}^{-1}$, $\alpha_{b}=5.21 \times 10^{-6} K^{-1}, \alpha_{c}=-1.80 \times 10^{-6} K^{-1}$, $\alpha_{V}=1.12 \times 10^{-6} K^{-1}$, respectively, corresponding to a linear CTE $\alpha_{l}=0.37 \times 10^{-6} K^{-1}(350-573 \mathrm{~K})$. These results are consistent with the values measured by dilatometry, confirming $\mathrm{HfMg}_{0.7} \mathrm{Zn}_{0.3} \mathrm{Mo}_{3} \mathrm{O}_{12}$ and $\mathrm{HfMg}_{0.8} \mathrm{Zn}_{0.2} \mathrm{Mo}_{3} \mathrm{O}_{12}$ being intrinsically ZTE materials. Figure 4D shows the changes of lattice constants and volume of $\mathrm{HfMgMo}_{3} \mathrm{O}_{12}$ with temperature.

Considering the fact that the intrinsic linear CTE of $\mathrm{HfMgMo}_{3} \mathrm{O}_{12}$ is $1.02 \times 10^{-6} \mathrm{~K}^{-1}$ (Marinkovic et al., $2008)$, it is reasonable to conclude that the incorporation of $\mathrm{Zn}^{2+}$ reduces the linear CTE and results in near ZTE of $\mathrm{HfMg}_{1-x} \mathrm{Zn}_{x} \mathrm{Mo}_{3} \mathrm{O}_{12}$. A comparison of the axial CTEs for $\mathrm{HfMgMo}_{3} \mathrm{O}_{12}, \mathrm{HfMg}_{0.8} \mathrm{Zn}_{0.2} \mathrm{Mo}_{3} \mathrm{O}_{12}$, and $\mathrm{HfMg}_{0.7} \mathrm{Zn}_{0.3} \mathrm{Mo}_{3} \mathrm{O}_{12}$ are given in Table 2. It is found that partial substitution of $\mathrm{Mg}^{2+}$ by $\mathrm{Zn}^{2+}$ leads to a significant reduction of the CTE in the $b$ axis and an increase of the NTE in the $c$-axis, resulting in a near ZTE and lower anisotropy of thermal expansion in the $\mathrm{Zn}$-containing compounds with respect to $\mathrm{HfMgMo}_{3} \mathrm{O}_{12}$ (see Table 2). The anisotropy of thermal expansion is defined as the maximum difference in the axial thermal expansion coefficients (Srikanth et al., 1992; Miller et al., 2013). The near zero linear thermal expansion and lower anisotropy property of the $\mathrm{Zn}$ containing compounds suggest that they could withstand higher thermal shock resistance.

The difference in the linear CTEs measured by XRD and dilatometry could be understood by the microstructural effects. In contrast to XRD measurement which gives the thermal expansion property of cell lattice, dilatometry reveals the bulk thermal expansion property, including both intrinsic (thermal expansion of a material arising from the lattice dynamics) and extrinsic (thermal expansion related to microstructures such as texture, grain size, grain boundaries, poses, and microcracks) effects. The difference measured by the two methods reflects the extrinsic effect in the sintered bulk, which, on heating, can add a small negative component to the intrinsic linear expansion coefficients. Generally speaking, a smaller difference suggests a better sintered quality of the bulk material which is desired for most applications. The absolute differences for the $\mathrm{Zn}$-containing compounds $\left(\Delta \alpha_{l}=0.42 \times 10^{-6} K^{-1}\right.$ for $x=0.2$ and $\Delta \alpha_{l}=0.38 \times 10^{-6} K^{-1}$ for $\left.x=0.3\right)$ are obviously smaller than that for $\mathrm{HfMgMo}_{3} \mathrm{O}_{12}\left(\Delta \alpha_{l}=1.17 \times 10^{-6} \mathrm{~K}^{-1}\right)$. It means that partial substitution of $\mathrm{Mg}^{2+}$ by $\mathrm{Zn}^{2+}$ in $\mathrm{HfMgMo}_{3} \mathrm{O}_{12}$ could 


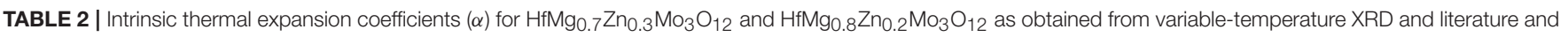
experimental values for $\mathrm{HfMgMo}_{3} \mathrm{O}_{12}$.

\begin{tabular}{|c|c|c|c|c|c|c|c|}
\hline Sample (Structure) & Fit range (K) & $\alpha_{a}\left(10^{-6} \mathrm{~K}^{-1}\right)$ & $\alpha_{b}\left(10^{-6} K^{-1}\right)$ & $\alpha_{c}\left(10^{-6} \mathrm{~K}^{-1}\right)$ & $\alpha_{I}\left(10^{-6} \mathrm{~K}^{-1}\right)$ & $\Delta \alpha_{\max }\left(10^{-6} \mathrm{~K}^{-1}\right)$ & References \\
\hline $\begin{array}{l}\mathrm{HfMgMo}_{3} \mathrm{O}_{12} \\
\text { (Orthorhombic) }\end{array}$ & $298-1,013$ & -3.44 & 8.0 & -1.49 & 1.02 & 11.44 & Marinkovic et al., 2008 \\
\hline $\begin{array}{l}\mathrm{HfMgMo}_{3} \mathrm{O}_{12} \\
\text { (Orthorhombic) }\end{array}$ & $253-573$ & -2.26 & 6.61 & -1.48 & 0.96 & 8.87 & This work \\
\hline $\begin{array}{l}\mathrm{HfMg}_{0.8} \mathrm{Zn}_{0.2} \mathrm{Mo}_{3} \mathrm{O}_{12} \\
\text { (Orthorhombic) }\end{array}$ & $350-573$ & -2.26 & 5.21 & -1.80 & 0.37 & 7.47 & This work \\
\hline $\begin{array}{l}\mathrm{HfMg}_{0.7} \mathrm{Zn}_{0.3} \mathrm{Mo}_{3} \mathrm{O}_{12} \\
\text { (Orthorhombic) }\end{array}$ & $350-573$ & -2.70 & 5.30 & -1.72 & 0.29 & 8 & This work \\
\hline
\end{tabular}
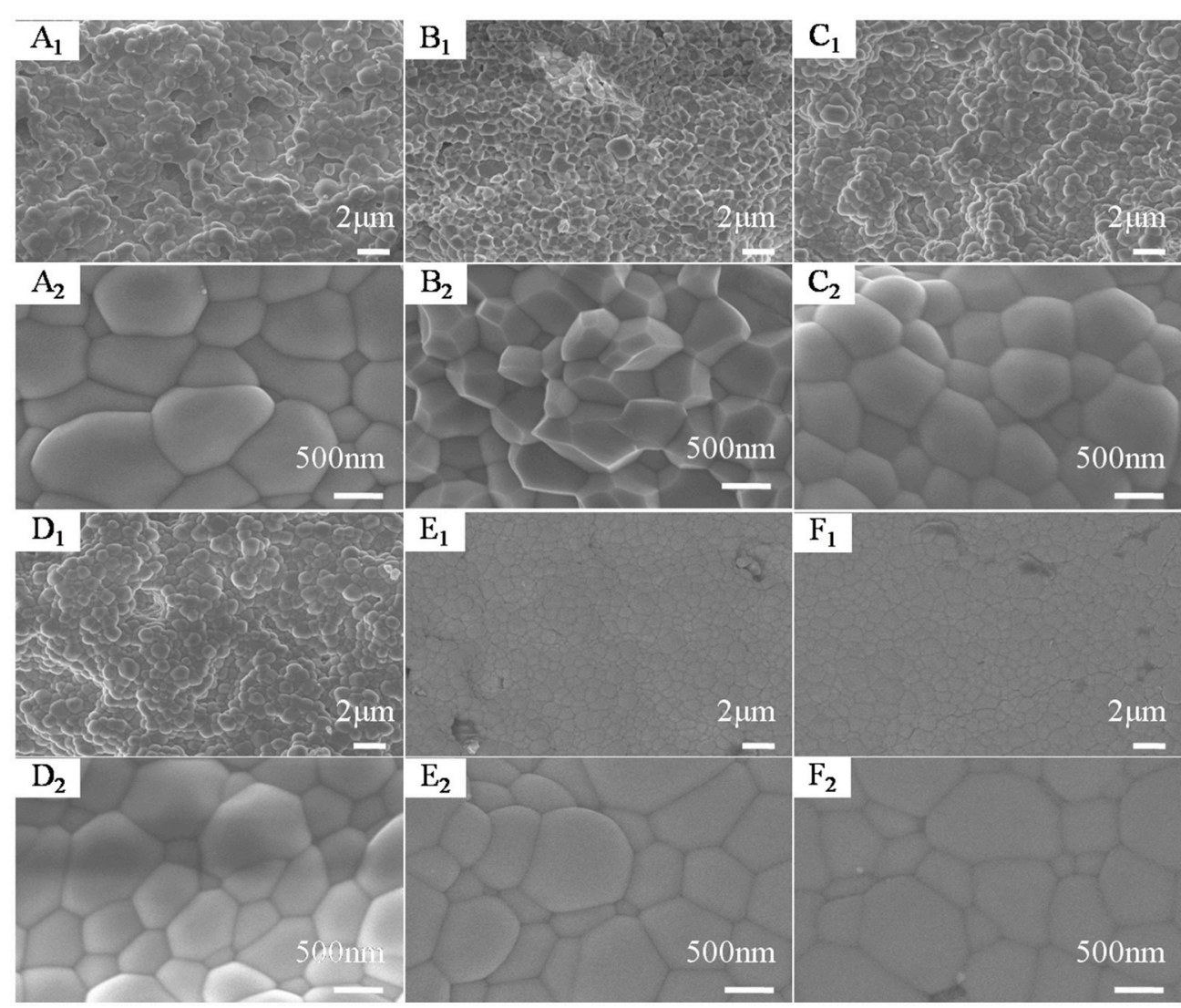

FIGURE 5 | SEM images of $\mathrm{HfMg}_{1-x} \mathrm{Zn}_{x} \mathrm{Mo}_{3} \mathrm{O}_{12}$ with $x=0.0$ (A), 0.1 (B), 0.2 (C), 0.3 (D), 0.4 (E), and 0.5 (F).

improve the sintering performance of the material and minimize the possible contributions of extrinsic effects. The analysis is supported by microstructural observation.

Figure 5 shows the SEM images of $\mathrm{HfMg}_{1-x} \mathrm{Zn}_{x} \mathrm{Mo}_{3} \mathrm{O}_{12}$ ceramics with $x=0.0$ (Figure 5A), 0.1 (Figure 5B), 0.2 (Figure 5C), 0.3 (Figure 5D), 0.4 (Figure 5E), and 0.5 (Figure 5F). The micro morphology of the sample for $x=$ 0.1 is dominated by well crystallized polyhdra or truncated polyhedra and the average particle size is obviously smaller than that of $\mathrm{HfMgMo}_{3} \mathrm{O}_{12}$. With increasing the content of $\mathrm{Zn}^{2+}$, the polyhedra become more rounded. Compared to
$\mathrm{HfMgMo}_{3} \mathrm{O}_{12}$, the incorporation of $\mathrm{Zn}^{2+}$ seems to lead to less pores in the ceramic bodies and pores can hardly be found in the solid solutions for $x=0.1-0.3$. It illustrates that proper amount incorporation of $\mathrm{Zn}^{2+}$ favors the formation of uniform distribution of particles and efficient reduction of porosity in the sintered body.

The schematic diagram of $\mathrm{HfMgMo}_{3} \mathrm{O}_{12}$ is given in Figure 6A to help us understand the mechanism of the phenomenons. In $\mathrm{HfMg}_{1-x} \mathrm{Zn}_{x} \mathrm{Mo}_{3} \mathrm{O}_{12}(\mathrm{x} \leq 0.5), \mathrm{Zn}^{2+}$ is expected to substitute for $\mathrm{Mg}^{2+}$ due to the same valence and similar cation radius and each $\mathrm{ZnO}_{6}$ octahedron shares all its corners with six 


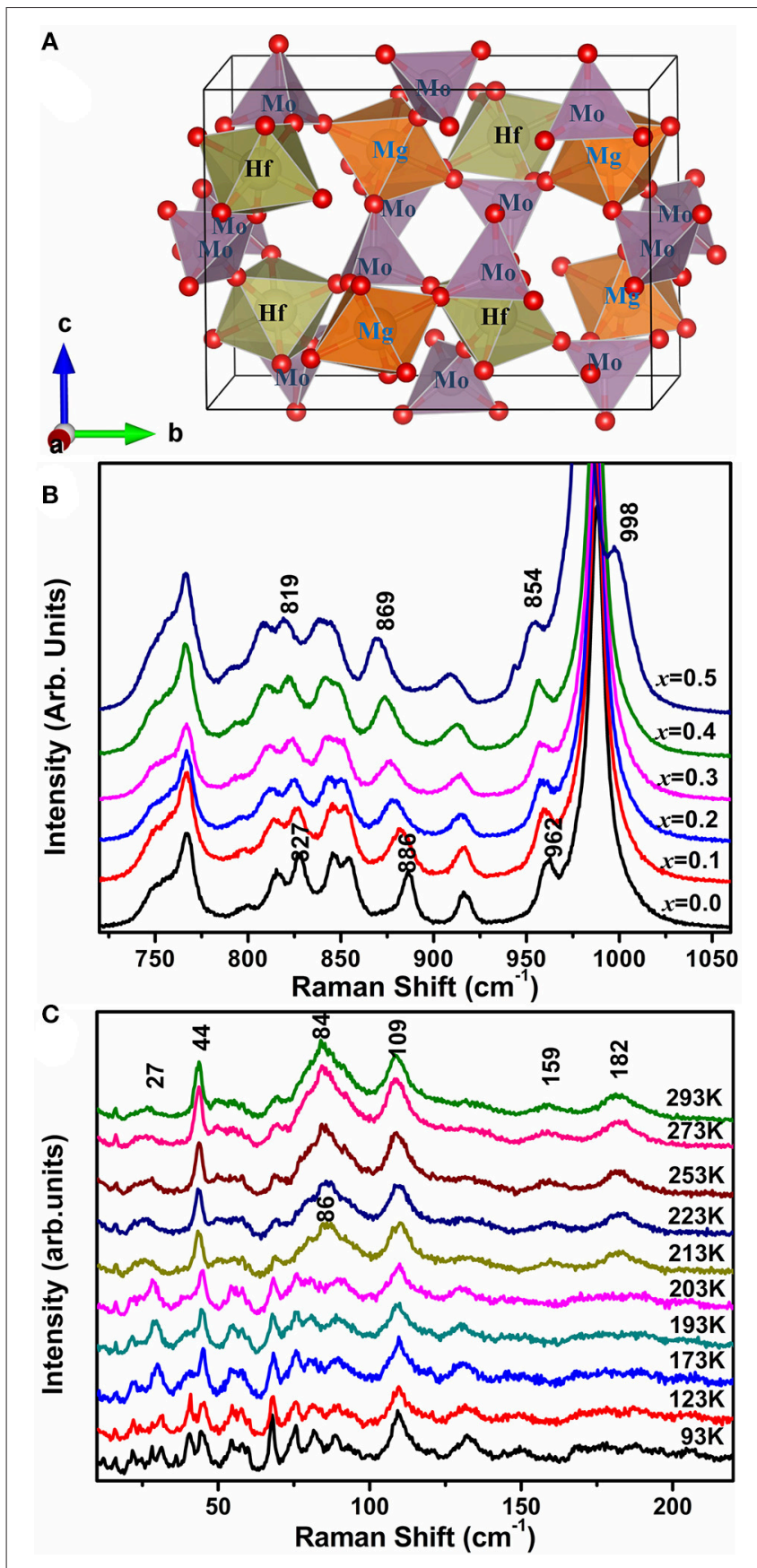

FIGURE 6 | (A) Schematic diagram of $\mathrm{HfMgMo}_{3} \mathrm{O}_{12}$ building block (red sphere indicates oxygen atom); (B) Raman spectra of $\mathrm{HfMg}_{1-x} \mathrm{Zn}_{x} \mathrm{Mo}_{3} \mathrm{O}_{12}$ in the high wavenumber regions; (C) Temperature-dependent Raman spectra of $\mathrm{HfMg}_{0.9} \mathrm{Zn}_{0.1} \mathrm{Mo}_{3} \mathrm{O}_{12}$ in the low wavenumber region.

$\mathrm{MoO}_{4}$ tetrahedra. In order to see the bond strength changes induced by local electronic environment upon substitution of $\mathrm{Zn}^{2+}$ for $\mathrm{Mg}^{2+}$, we show in Figure 6B the Raman spectra of the stretching region for $x=0.0,0.1,0.2,0.3,0.4$, and 0.5 . It is obvious that all the stretching modes shift successively to lower wavenumbers with increasing the content of $\mathrm{Zn}^{2+}$, indicating a softening of the Mo-O bonds upon incorporation of $\mathrm{Zn}^{2+}$. Once an $\mathrm{Mg}^{2+}$ is replaced by $\mathrm{Zn}^{2+}$, the local electronic equilibrium around the $\mathrm{MoO}_{4}$ tetrahedron is broken. $\mathrm{Zn}^{2+}$ has obviously a higher electronegativity and ability to drag electrons to the $\mathrm{ZnO}_{6}$ octahedron from its connected six $\mathrm{MoO}_{4}$ tetrahedra than $\mathrm{Mg}^{2+}$, resulting in the weakening of the Mo$\mathrm{O}$ bonds. The differences in ionic radius and electronegativity could cause a slight rotation of the connected polyhedra and hence the M-O-M linkages. This is probably the reason that the positive expansion of the $b$-axis is pronouncedly reduced and the NTE in the $c$-axes become more negative, resulting hence in a lower anisotropy in thermal expansion and nearzero CTEs of the Zn-containing compounds. Due to the large difference in electronegativity between $\mathrm{Zn}^{2+}$ (1.65 Pauling) and $\mathrm{Mg}^{2+}$ (1.31 Pauling), the more of $\mathrm{Zn}^{2+}$ is incorporated, the more of the $\mathrm{MoO}_{4}$ tetrahedra get distorted as revealed by Raman spectroscopy, resulting in larger distortion and instability of the lattice. When the forming energy for the single phase exceeds that for the multi-phases, then the multi-phases form.

Figure 6C shows the temperature-dependent Raman spectra of $\mathrm{HfMg}_{0.9} \mathrm{Zn}_{0.1} \mathrm{Mo}_{3} \mathrm{O}_{12}$ in the low wavenumber region. Obvious change of the Raman spectra occur between 203 and $213 \mathrm{~K}$, corresponding to the monoclinic to orthorhombic phase transition, such as the appearance of new Raman modes at about $27,44,86,159$, and $182 \mathrm{~cm}^{-1}$. The modes at about 44 and $86 \mathrm{~cm}^{-1}$ are split into two or three modes in the low temperature phase and become degenerated in the high temperature phase. The low wavenumber modes arise from the external librational and translational vibrations of the connected octahedra-tetrahedra, or the librational and translational motions of metal ions in the $\mathrm{Hf}(\mathrm{Mg} / \mathrm{Zn})-\mathrm{O}-\mathrm{Mo}$ linkages, which can also be regarded as the transverse vibrations of the bridging oxygen from the point of view of relative movement. Such an harmonic vibrations along with the distortion of the polyhedra are believed to be the origin of the NTE in the open frame work structure since they bring the two end atoms closer upon heating (Evans, 1999; Ding et al., 2008; Marinkovic et al., 2009; Wang et al., 2013).

\section{CONCLUSION}

Solid solutions of $\mathrm{HfMg}_{1-x} \mathrm{Zn}_{x} \mathrm{Mo}_{3} \mathrm{O}_{12}$ with near-ZTE are successfully synthesized by solid state reaction and the effects of $\mathrm{Zn}^{2+}$ incorporation on the phase formation, thermal expansion, phase transition, and vibrational properties and micro-morphologies are investigated by $\mathrm{XRD}$, dilatometry, Raman spectroscopy, and SEM. It is shown that (i) single phase formation is only possible for $x \leq 0.5$, otherwise, additional phases of $\mathrm{HfMo}_{2} \mathrm{O}_{8}$ and $\mathrm{ZnMoO}_{4}$ generate; (ii) $\mathrm{HfMg}_{1-x} \mathrm{Zn}_{x} \mathrm{Mo}_{3} \mathrm{O}_{12}$ crystallize in an orthorhombic structure for $x \leq 0.4$ and in a monoclinic structure for $x=0.5$ at RT; (iii) The phase transition temperature from monoclinic to orthorhombic structure increases with the content of $\mathrm{Zn}^{2+}$, which occurs within 168-178, 203-213, 223-233, 258-268, 283-293, and $318-328 \mathrm{~K}$ for $x=0.0,0.1,0.2,0.3,0.4$, and 0.5 , respectively; (iv) The incorporation of $\mathrm{Zn}^{2+}$ leads to an 
pronounced reduction in the positive expansion of the $b$-axis and an enhanced NTE in $c$-axes, making the Zn-containing materials exhibit near-ZTE over a wide temperature range and lower anisotropy in thermal expansion in the orthorhombic phase; (v) Replacement of $\mathrm{Mg}^{2+}$ by $\mathrm{Zn}^{2+}$ breaks the local electronic equilibrium around the $\mathrm{MoO}_{4}$ tetrahedron and weakens the Mo-O bonds, leading to obvious red shifts of all the Mo-O stretching modes with increasing the content of $\mathrm{Zn}^{2+}$ due to obviously higher electronegativity of $\mathrm{Zn}^{2+}$ than $\mathrm{Mg}^{2+}$; (vi) The incorporation of $\mathrm{Zn}^{2+}$ improves sintering property of samples, minimizing the possible contributions of extrinsic effects such as pores, which is preferred for most applications.

\section{REFERENCES}

Ahsaine, H. A., Zbair, M., Ezahri, M., Benlhachemi, A., Bakiz, B., Guinneton, F., et al. (2016). Structural and temperature-dependent vibrational analyses of the non-centrosymmetric $\mathrm{ZnMoO}_{4}$ molybdate. J. Mater. Environ. Sci. 7, 907-915.

Allen, S., Ward, R. J., Hampson, M. R., Gover, R. K., and Evans, J. S. (2004). Structures and phase transitions of trigonal $\mathrm{ZrMo}_{2} \mathrm{O}_{8}$ and $\mathrm{HfMo}_{2} \mathrm{O}_{8}$. Acta Crystallogr. B. 60, 32-40. doi: 10.1107/S01087681030 25138

Azuma, M., Chen, W., Seki, H., Czapski, M., Olga, S., Oka, K., et al. (2011). Colossal negative thermal expansion in $\mathrm{BiNiO}_{3}$ induced by intermetallic charge transfer. Nat. Commun. 2:347. doi: 10.1038/ncomms1361

Baiz, T. I., Gindhart, A. M., Kraemer, S. K., and Lind, C. (2008). Synthesis of $\mathrm{MgHf}\left(\mathrm{WO}_{4}\right)_{3}$ and $\mathrm{MgZr}\left(\mathrm{WO}_{4}\right)_{3}$ using a non-hydrolytic sol-gel method. J. Solgel Sci. Technol. 47, 128-130. doi: 10.1007/s10971-008-1 765-5

Bridges, F., Keiber, T., Juhas, P., Billinge, S. J. L., Sutton, L., Wilde, J., et al. (2014). Local vibrations and negative thermal expansion in $\mathrm{ZrW}_{2} \mathrm{O}_{8}$. Phys. Rev. Lett. 112:045505. doi: 10.1103/PhysRevLett.112.045505

Chen, D. X., Yuan, B. H., Cheng, Y. G., Ge, X. H., Jia, Y., Liang, E. J., et al. (2016). Phase transition and near-zero thermal expansion in $\mathrm{ZrFeMo}_{2} \mathrm{VO}_{12}$. Phys. Lett. A 380, 4070-4074. doi: 10.1016/j.physleta.2016.10.009

Chen, J., Hu, L., Deng, J., and Xing, X. (2015). Negative thermal expansion in functional materials: controllable thermal expansion by chemical modifications. Chem. Soc. Rev. 44, 3522-3567. doi: 10.1039/C4CS00461B

Chen, J., Wang, F. F., Huang, Q. Z., Hu, L., Song, X. P., Deng, J. X., et al. (2013). Effectively control negative thermal expansion of single-phase ferroelectrics of $\mathrm{PbTiO}_{3}-(\mathrm{Bi}, \mathrm{La}) \mathrm{FeO}_{3}$ over a giant range. Sci. Rep. 3:2458. doi: 10.1038/srep02458

Cheng, Y. G., Liang, Y., Ge, X. H., Liu, X. S., Yuan, B. H., Guo, J., et al. (2016a). A novel material of $\mathrm{HfScMo}_{2} \mathrm{VO}_{12}$ with negative thermal expansion and intense white-light emission. RSC Adv. 6, 53657-53661. doi: 10.1039/C6RA09666B

Cheng, Y. G., Liang, Y., Mao, Y. C., Ge, X. H., Yuan, B. H., Guo, J., et al. (2017). A novel material of $\mathrm{HfScW}_{2} \mathrm{PO}_{12}$ with negative thermal expansion from $140 \mathrm{~K}$ to $1469 \mathrm{~K}$ and intense blue photoluminescence. Mater. Res. Bull. 85, 176-180. doi: 10.1016/j.materresbull.2016.09.008

Cheng, Y. G., Mao, Y. C., Liu, X. S., Yuan, B. H., Chao, M. J., and Liang, E. J. (2016b). Near-zero thermal expansion of $\mathrm{In}_{2(1-\mathrm{x})}(\mathrm{HfMg})_{\mathrm{x}} \mathrm{Mo}_{3} \mathrm{O}_{12}$ with tailored phase transition. Chin. Phys. $B$ 25:86501. doi: 10.1088/1674-1056/25/8/086501

Das, S., Das, S., and Das, K. (2013). Low temperature synthesis of negative thermal expansion $\mathrm{Y}_{2} \mathrm{~W}_{3} \mathrm{O}_{12}$. J. Mater. Eng. Perf. 22, 3357-3363. doi: $10.1007 / \mathrm{s} 11665-013-0652-6$

Ding, P., Liang, E. J., Jia, Y., and Du, Z. Y. (2008). Electronic structure, bonding and phonon modes in the negative thermal expansion materials of $\mathrm{Cd}(\mathrm{CN})_{2}$ and $\mathrm{Zn}(\mathrm{CN})_{2}$. J. Phys. Condens. Matter 20:275224. doi: 10.1088/0953-8984/20/27/275224

Evans, J. S. O. (1999). Negative thermal expansion materials. J. Chem. Soc. Dalton Trans. 1999, 3317-3326. doi: 10.1039/a904297k

\section{AUTHOR CONTRIBUTIONS}

EL conceived the idea and supervised the research. SL and RS are in charge of the synthesis and part measurements of the materials. $\mathrm{XG}, \mathrm{HY}$, and DC are in charge of the thermal expansion and Raman characterization. JG and MC are in charge of the XRD characterization and structural analyses. SL, XG, and EL are in charge of the manuscript preparation.

\section{ACKNOWLEDGMENTS}

This work was supported by the National Natural Science Foundation of China (No. 11574276; No. 51302249).

Evans, J. S. O., Hu, Z., Jorgensen, J. D., Argyriou, D. N., Short, S., and Sleight, A. W. (1997a). Compressibility, phase transitions, and oxygen migration in zirconium tungstate, $\mathrm{ZrW}_{2} \mathrm{O}_{8}$. Science 275, 61-65. doi: 10.1126/science.275.5296.61

Evans, J. S. O., Mary, T. A., and Sleight, A. W. (1997b). Negative thermal expansion in a large molybdate and tungstate family. J. Solid State Chem. 133, 580-583. doi: 10.1006/jssc.1997.7605

Evans, J. S. O., Mary,T. A., Vogt, T., Subramanian, M. A., and Sleight, A. W. (1996). Negative thermal expansion in $\mathrm{ZrW}_{2} \mathrm{O}_{8}$ and $\mathrm{HfW}_{2} \mathrm{O}_{8}$. Chem. Mater. 8, 2809-2823. doi: 10.1021/cm9602959

Ge, X., Liu, X., Cheng, Y., Yuan, B., Chen, D., Chao, M., et al. (2016c). Negative thermal expansion and photoluminescence properties in a novel material $\mathrm{ZrScW}_{2} \mathrm{PO}_{12}$. J. Appl. Phys. 120:205101. doi: 10.1063/1.4968546

Ge, X. H., Mao, Y. C., Li, L., Li, L. P., Yuan, N., Cheng, Y. G., et al. (2016a). Phase transition and negative thermal expansion property of $\mathrm{ZrMnMo}_{3} \mathrm{O}_{12}$. Chin. Phys. Lett. 33:046503. doi: 10.1088/0256-307X/33/4/046503

Ge, X. H., Mao, Y. C., Liu, X. S., Cheng, Y. G., Yuan, B. H., Chao, M. J., et al. (2016b). Negative thermal expansion and broad band photoluminescence in a novel material of $\mathrm{ZrScMo}_{2} \mathrm{VO}_{12}$. Sci. Rep. 6:24832. doi: 10.1038/srep24832

Gindhart, A. M., Lind, C., and Green, M. (2008). Polymorphism in the negative thermal expansion material magnesium hafnium tungstate. J. Mater. Res. 23, 210-213. doi: 10.1557/JMR.2008.0013

Hu, L., Chen, J., Fan, L. L., Ren, Y., Rong, Y. C., Pan, Z., et al. (2015). ChemInform abstract: zero thermal expansion and ferromagnetism in cubic $\mathrm{Sc}_{1-\mathrm{x}} \mathrm{M}_{\mathrm{x}} \mathrm{F}_{3}$ (M: Ga, Fe) over a wide temperature range. Cheminform 46:13566. doi: $10.1002 /$ chin.201507003

Lama, P., Das, R. K., Smith, V. J., and Barbour, L. J. (2014). A combined stretching-tilting mechanism produces negative, zero and positive linear thermal expansion in a semi-flexible Cd(II)-MOF. Chem. Commun. 50, 6464-6467. doi: 10.1039/C4CC02634A

Li, F., Liu, X. S., Song, W. B., Yuan, B. H., Cheng, Y. G., Yuan, H. L., et al. (2014). Phase transition, crystal water and low thermal expansion behavior of $\mathrm{Al}_{2-2 \mathrm{x}}(\mathrm{ZrMg})_{\mathrm{x}} \mathrm{W}_{3} \mathrm{O}_{12} \cdot \mathrm{n}\left(\mathrm{H}_{2} \mathrm{O}\right)$. J. Solid State Chem. 218, 15-22. doi: 10.1016/j.jssc.2014.06.009

Li, T., Ge, X. H., Liu, X. S., Cheng, Y. G., Liu, Y. Y., Yuan, H. L., et al. (2016). Enhanced negative thermal expansion by solid solution of $\mathrm{HfMgMo}_{1.5} \mathrm{~W}_{1.5} \mathrm{O}_{12}$. Mater. Expr. 6, 515-520. doi: 10.1166/mex.2016.1337

Li, T., Liu, X. S., Cheng, Y. G., Ge, X. H., Zhang, M. D., Lian, H., et al. (2017). Zero and controllable thermal expansion in $\mathrm{HfMgMo}_{3-\mathrm{x}} \mathrm{W}_{\mathrm{X}} \mathrm{O}_{12}$. Chin. Phys. $B$ 26:348. doi: 10.1088/1674-1056/26/1/016501

Li, Z. Y., Song, W. B., and Liang, E. J. (2011). Structures, phase transition, and crystal water of $\mathrm{Fe}_{2-\mathrm{x}} \mathrm{Y}_{\mathrm{x}} \mathrm{Mo}_{3} \mathrm{O}_{12}$. J. Phys. Chem. C 115, 17806-17811. doi: $10.1021 /$ jp201962b

Liang, E. J., Huo, H. L., Wang, J. P., and Chao, M. J. (2008a). Effect of water species on the phonon modes in orthorhombic $\mathrm{Y}_{2}\left(\mathrm{MoO}_{4}\right)_{3}$ revealed by Raman spectroscopy. J. Phys. Chem. C 112, 6577-6581. doi: 10.1021/jp8013332

Liang, E. J., Liang, Y., Zhao, Y., Liu, J., and Jiang, Y. (2008b). Low-frequency phonon modes and negative thermal expansion in $\mathrm{A}\left(\mathrm{MO}_{4}\right)_{2}(\mathrm{~A}=\mathrm{Zr}$, $\mathrm{Hf}$ and $\mathrm{M}$ $=\mathrm{W}, \mathrm{Mo}$ ) by Raman and Terahertz time-domain spectroscopy. J. Phys. Chem. A 112, 12582-12587. doi: 10.1021/jp805256d 
Liu, X. S., Cheng, Y. G., Liang, E. J., and Chao, M. J. (2014). Interaction of crystal water with the building block in $\mathrm{Y}_{2} \mathrm{Mo}_{3} \mathrm{O}_{12}$ and the effect of $\mathrm{Ce}^{3+}$ doping. Phys. Chem. Chem. Phys. 16, 12848-12857. doi: 10.1039/c4cp00144c

Liu, X. S., Wang, J. Q., Fan, C. Z., Shang, R., Cheng, F. X., Yuan, B. H., et al. (2015). Control of reaction pathways for rapid synthesis of negative thermal expansion ceramic $\mathrm{Zr}_{2} \mathrm{P}_{2} \mathrm{WO}_{12}$ with uniform microstructure. Int. J. Appl. Ceram. Technol. 12, E28-E33. doi: 10.1111/ijac.12201

Liu, Y. Y., Yuan, B. H., Cheng, Y. G., Liang, E. J., Ge, X. H., Yuan, H. L., et al. (2018). Phase transition and negative thermal expansion of $\mathrm{HfMnMo}_{3} \mathrm{O}_{12}$. Mater. Res. Bull. 99, 255-259. doi: 10.1016/j.materresbull.2017.11.009

Long, Y. W., Hayashi, N., Saito, T., Azuma, M., Muranaka, S., and Shimakawa, Y. (2009). Temperature-induced A-B intersite charge transfer in an A-site-ordered $\mathrm{LaCu}_{3} \mathrm{Fe}_{4} \mathrm{O}_{12}$ perovskite. Cheminform 40, 60-63. doi: 10.1002/chin.200947022

Marinkovic, B. A., Ari, M., Avillez, R. R. D., Rizzo, F., Ferreira, F. F., Miller, K. J., et al. (2009). Correlation between $\mathrm{AO}_{6}$ polyhedral distortion and negative thermal expansion in orthorhombic $\mathrm{Y}_{2} \mathrm{Mo}_{3} \mathrm{O}_{12}$ and related materials. Chem. Mater. 21, 2886-2894. doi: 10.1021/cm900650c

Marinkovic, B. A., Jardim, P. M., Ari, M., Avillez, R. R. D., Rizzo, F., and Ferreira, F. F. (2008). Low positive thermal expansion in $\mathrm{HfMgMo}_{3} \mathrm{O}_{12}$. Phys. Status Solidi 245, 2514-2519. doi: 10.1002/pssb.200880262

Miller, K. J., Johnson, M. B., White, M. A., and Marinkovic, B. A. (2012). Lowtemperature investigations of the open-framework material $\mathrm{HfMgMo}_{3} \mathrm{O}_{12}$. Solid State Commun. 152, 1748-1752. doi: 10.1016/j.ssc.2012.06.022

Miller, K. J., Romao, C. P., Bieringer, M., Marinkovic, B. A., Prisco, L., and White, M. A. (2013). Near-zero thermal expansion in $\operatorname{In}(\mathrm{HfMg})_{0.5} \mathrm{Mo}_{3} \mathrm{O}_{12}$. J. Am. Ceram. Soc. 96, 561-566. doi: 10.1111/jace.12085

Omote, A., Yotsuhashi, S., Zenitani, Y., and Yamada, Y. (2011). High ion conductivity in $\mathrm{MgHf}\left(\mathrm{WO}_{4}\right)_{3}$ solids with ordered structure: 1-D alignments of $\mathrm{Mg}^{2+}$ and $\mathrm{Hf}{ }^{4+}$ ions. J. Am. Ceram. Soc. 94, 2285-2288. doi: 10.1111/j.1551-2916.2011.04644.x

Peng, X., Chen, J., Lin, K., Fan, L. L., Rong, Y. C., Deng, J. X., et al. (2016). Structure and control of negative thermal expansion of $\mathrm{Nd} / \mathrm{Sm}$ substituted $0.5 \mathrm{PbTiO}_{3}$ 0.5BiFeO ${ }_{3}$ ferroelectrics. RSC Adv. 6, 32979-32982. doi: 10.1039/C6RA03774G

Peng, Z., Sun, Y. Z., and Peng, L. M. (2014). Hydrothermal synthesis of $\mathrm{ZrW}_{2} \mathrm{O}_{8}$ nanorods and its application in $\mathrm{ZrW}_{2} \mathrm{O}_{8} / \mathrm{Cu}$ composites with controllable thermal expansion coefficients. Mater. Des. 54, 989-994. doi: $10.1016 /$ j.matdes.2013.09.012

Pryde, A. K. A., Hammonds, K. D., Dove, M. T., Heine, V., Gale, J. D., and Warren, M. C. (1996). Origin of the negative thermal expansion in $\mathrm{ZrW}_{2} \mathrm{O}_{8}$ and $\mathrm{ZrV}_{2} \mathrm{O}_{7}$. J. Phys. Condens. Matter 8:10973. doi: 10.1088/0953-8984/8/50/023

Qu, B. Y., He, H. Y., and Pan, B. C. (2012).Origin of the giant negative thermal expansion in $\mathrm{Mn}_{3}\left(\mathrm{Cu}_{0.5} \mathrm{Ge}_{0.5}\right)$ N. Adv. Conden. Matter Phys. 2012, 275-281. doi: 10.1155/2012/913168

Reichelt, W., Weber, T., Söhnel, T., and Däbritz, S. (2000). Mischkristallbildung im system $\mathrm{CuMoO}_{4} / \mathrm{ZnMoO}_{4}$. Z. Anorgan. Allgem. Chem. 626, 2020-2027. doi: 10. 1002/1521-3749(200009)626:9\&lt;2020::AID-ZAAC2020\&gt;3.0.CO;2-K

Song, W. B., Liang, E. J., Liu, X. S., Li, Z. Y., Yuan, B. H., and Wang, J. Q. (2013). A negative thermal expansion material of $\mathrm{ZrMgMo}_{3} \mathrm{O}_{12}$. Chin. Phys. Lett. 30:126502. doi: 10.1088/0256-307X/30/12/126502

Song, W. B., Wang, J. Q., Li, Z. Y., Liu, X. S., Yuan, B. H., and Liang, E. J. (2014a). Phase transition and thermal expansion property of $\mathrm{Cr}_{2-\mathrm{x}} \mathrm{Zr}_{0.5 \mathrm{x}} \mathrm{Mg}_{0.5 \mathrm{x}} \mathrm{Mo}_{3} \mathrm{O}_{12}$ solid solution. Chin. Phys. B 23:433. doi: 10.1088/1674-1056/23/6/066501

Song, W. B., Yuan, B. H., Liu, X. S., Li, Z. Y., Wang, J. Q., and Liang, E. J. (2014b). Tuning the monoclinic-to-orthorhombic phase transition temperature of $\mathrm{Fe}_{2} \mathrm{Mo}_{3} \mathrm{O}_{12}$ by substitutional co-incorporation of $\mathrm{Zr}^{4+}$ and $\mathrm{Mg}^{2+}$. J. Mater. Res. 29, 849-855. doi: 10.1557/jmr.2014.63
Srikanth, V., Subbarao, E. C., and Rao, G. V. (1992). Thermal expansion anisotropy, microcracking and acoustic emission of $\mathrm{Nb}_{2} \mathrm{O}_{5}$ ceramics.Ceram. Int. 18, 251-261. doi: 10.1016/0272-8842(92)90103-K

Suzuki, T., and Omote, A. (2004). Negative thermal expansion in $(\mathrm{HfMg})\left(\mathrm{WO}_{4}\right)_{3}$. J. Am. Ceram. Soc. 87, 1365-1367. doi: 10.1111/j.1151-2916.2004.tb07737.x

Suzuki, T., and Omote, A. (2006). Zero thermal expansion in $\left(\mathrm{Al}_{2 \mathrm{X}}(\mathrm{HfMg})_{1-\mathrm{x}}\right)\left(\mathrm{WO}_{4}\right)_{3}$. J. Am. Ceram. Soc. 89, 691-693. doi: 10.1111/j.1551-2916.2005.00729.x

Takenaka, K., and Takagi, H. (2005). Giant negative thermal expansion in Ge-doped anti-perovskite manganese nitrides. Appl. Phys. Lett. 87:261902. doi: 10.1063/1.2147726

Tallentire, S. E., Child, F., Fall, I., Vella-Zarb, L., Evans, I. R., Tucker, M. G., et al. (2013). Systematic and controllable negative, zero, and positive thermal expansion in cubic $\mathrm{Zr}_{1-\mathrm{x}} \mathrm{Sn}_{\mathrm{x}} \mathrm{Mo}_{2} \mathrm{O}_{8}$. J. Am. Chem. Soc. 135, 12849-12856. doi: $10.1021 /$ ja4060564

Wang, L., Wang, F., Yuan, P. F., Sun, Q., Liang, E. J., Jia, Y., et al. (2013). Negative thermal expansion correlated with polyhedral movements and distortions in orthorhombic $\mathrm{Y}_{2} \mathrm{Mo}_{3} \mathrm{O}_{12}$. Mater. Res. Bull. 48, 2724-2729. doi: 10.1016/j.materresbull.2013.04.001

Wang, X., Huang, Q. , Deng, J., Yu, R., Chen, J., and Xing, X. (2011). Phase transformation and negative thermal expansion in $\mathrm{TaVO}_{5}$. Inorg. Chem. 50, 2685-2690. doi: 10.1021/ic200003n

Wu, M, Liu, X., Chen, D. , Huang, Q., Wu, H., and Liu, Y. (2014). Structure, phase transition, and controllable thermal expansion behaviors of $\mathrm{Sc}_{2-\mathrm{x}} \mathrm{Fe}_{\mathrm{X}} \mathrm{Mo}_{3} \mathrm{O}_{12}$. Inorg. Chem. 53, 9206-9212. doi: 10.1021/ic501271t

Wu, M. M., Peng, J., Han, S. B., Hu, Z. B., Liu, Y. T., and Chen, D. F. (2012). Phase transition and negative thermal expansion properties of $\mathrm{Sc}_{2-\mathrm{x}} \mathrm{Cr}_{\mathrm{x}} \mathrm{Mo}_{3} \mathrm{O}_{12}$. Ceram. Int. 38, 6525-6529. doi: 10.1016/j.ceramint.2012.05.033

Wu, M. M., Xiao, X. L., Hu, Z. B., Liu, Y. T., and Chen, D. F. (2009). Controllable thermal expansion and phase transition in $\mathrm{Yb}_{2-\mathrm{X}} \mathrm{Cr}_{\mathrm{X}} \mathrm{Mo}_{3} \mathrm{O}_{12}$. Solid State Sci. 11,325-329. doi: 10.1016/j.solidstatesciences.2008.08.002

Xiao, X., Zhou, W. J., Liu, X. S., Chao, M. J., Li, Y. C., Zhang, N., et al.,(2014). Electrical properties of $\mathrm{Al}-\mathrm{ZrMgMo}_{3} \mathrm{O}_{12}$ with controllable thermal expansion. Ceram. Int. 41, 2361-2366. doi: 10.1016/j.ceramint.2014.10.048

Yamada, I., Shiro, K., Etani, H., Marukawa, S., Hayashi, N., Mizumaki, M., et al. (2016). Valence transitions in negative thermal expansion material $\mathrm{SrCu}_{3} \mathrm{Fe}_{4} \mathrm{O}_{12}$. Inorg. Chem. 53, 10563-10569. doi: 10.1021/ic501665c

Yan, J., Sun, Y., Wang, C., Chu, L. H., Shi, Z. X., Deng, S. H., et al. (2014). Study of structure of $\mathrm{Mn}_{3} \mathrm{Cu}_{0.5} \mathrm{Ge}_{0.5} \mathrm{~N} / \mathrm{Cu}$ composite with nearly zero thermal expansion behavior around room temperature. Scr. Mater. 84-85, 19-22. doi: 10.1016/j.scriptamat.2014.04.010

Yang, X. B., Cheng, X. N., Yan, X. H., Yang, J., Fu, T. B., and Qiu, J. (2007). Synthesis of $\mathrm{ZrO}_{2} / \mathrm{ZrW}_{2} \mathrm{O}_{8}$ composites with low thermal expansion. Compos. Sci. Technol. 67, 1167-1171. doi: 10.1016/j.compscitech.2006.05.012

Conflict of Interest Statement: The authors declare that the research was conducted in the absence of any commercial or financial relationships that could be construed as a potential conflict of interest.

Copyright (๑) $2018 \mathrm{Li}, \mathrm{Ge}$, Yuan, Chen, Guo, Shen, Chao and Liang. This is an open-access article distributed under the terms of the Creative Commons Attribution License (CC BY). The use, distribution or reproduction in other forums is permitted, provided the original author(s) and the copyright owner are credited and that the original publication in this journal is cited, in accordance with accepted academic practice. No use, distribution or reproduction is permitted which does not comply with these terms. 